\title{
The electronic nose: a fast and efficient tool for characterizing dates
}

\author{
Marc Lebrun $^{a *}$, Claire BILlot $^{b}$, Hasnaâ HARRAK ${ }^{c}$, Guy SELF ${ }^{a}$
}

a CIRAD, Persyst, UMR Qualisud, 34398 Montpellier Cedex 5, France lebrun.m@cirad.fr

b CIRAD, Bios, UMR

Développement et Adaptation des Plantes, 34398 Montpellier Cedex 5, France

c INRA, UR Amélioration des plantes et de la qualité, BP 533, Marrakech 40000, Morocoo

\section{${ }^{*}$ Correspondence and reprints}

Received 15 April 2007 Accepted 14 August 2007

Fruits, 2007, vol. 62, p. 377-382 (C) 2007 Cirad/EDP Sciences All rights reserved DOI: $10.1051 /$ fruits:2007035 www.fruits-journal.org RESUMEN ESPAÑOL, p. 382

\section{The electronic nose: a fast and efficient tool for characterizing dates.}

Abstract - Introduction. Aroma is often used as a fruit quality marker. Several researchers have used the analysis of volatile compounds to characterize dates (Phoenix dactylifera). Nevertheless, it is difficult to analyze this subtle aroma in spite of the many techniques available, such as liquidliquid extractions and headspace analysis. The global approach of the e-nose with a minimum handling of the sample is a fast and efficient alternative to these techniques. This rather new tool, simulating the behavior of the human nose, thus aroused our interest for application to dates. Materials and methods. Dates were harvested, in 2005 , at the Tamar stage from nine date varieties, in Zagora, Morocco. They were frozen after harvest and sent by air to the laboratory of CIRAD (Montpellier, France). All data were collected at the same time. Five hundred $g$ of dates were taken at random, pitted and cut into small pieces. After homogenization, an aliquot of $3.0 \mathrm{~g}$ was put into a 10-mL headspace flask and immediately sealed. Six replicates per sample were prepared for later electronic-nose analysis. An electronic nose (e-nose) from Alpha MOS, equipped with Metal Oxide Sensors (MOS), was used. Data were analyzed using Principal Component Analysis (PCA). The Discrimination Index (DI), created by Alpha MOS, was used to describe the discriminatory power of the groups' separation. Alpha MOS considers that good discrimination and reliability are achieved for DI over $80 \%$. Results. Discrimination indexes $>88 \%$ and means of the coefficients of variation obtained for each sensor $<4 \%$ demonstrate the high performance and good reproducibility of the e-nose. Conclusion. The e-nose is sensitive to date volatile emissions. All the date varieties studied were well separated. This fast screening technique, creating a specific olfactory fingerprint as a genuine identity card, could be used to follow changes in maturity, assure the identity of lots of dates and detect adulteration.

Morocco / Phoenix dactylifera / fruits / varieties / volatile compounds / olfaction / measuring instruments

\section{Le nez électronique : un outil rapide et efficace pour la caractérisation des dattes.}

Résumé - Introduction. Les arômes sont souvent utilisés comme marqueur de la qualité du fruit. Pour la caractérisation des dattes (Phoenix dactylifera), plusieurs chercheurs ont utilisé l'analyse des composés volatils. Néanmoins, il est difficile d'analyser cet arôme ténu malgré les nombreuses techniques disponibles, comme les extractions liquide-liquide et l'analyse d'espace de tête. L'utilisation du nez électronique, qui nécessite une manipulation minimale de l'échantillon, est une autre technique ; elle est rapide et efficace. Cet outil assez nouveau, qui simule le comportement du nez humain, a donc éveillé notre intérêt pour une application aux dattes. Matériel et méthodes. Les dattes de neuf variétés de dattier ont été récoltées, en 2005, au stade Tamar, à Zagora, Maroc. Elles ont été congelées après récolte et envoyées par avion au laboratoire du CIRAD (Montpellier, France). Toutes les données ont été collectées en même temps. Cinq cents g de dattes ont été prélevés au hasard parmi la récolte. Celles-ci ont été dénoyautées et découpées en petits morceaux. Après homogénéisation, une partie aliquote de $3.0 \mathrm{~g}$ a été mise dans un flacon d'espace de tête de $10 \mathrm{~mL}$ et immédiatement scellée. Six répétitions par échantillon ont été préparées pour les analyses au nez électronique ultérieures. Un nez électronique (Alpha MOS) équipé de capteurs à base d'oxydes métalliques a été utilisé. Les données ont été traitées par une analyse en composantes principales (ACP). L'index de discrimination (DI), créé par Alpha MOS, a été utilisé pour décrire le pouvoir discriminatoire de la séparation des groupes. Alpha MOS considère que de bonnes discrimination et fiabilité sont obtenues pour des DI supérieures à $80 \%$. Résultats. Des index de discrimination supérieurs à $88 \%$ et les moyennes des coefficients de variation obtenus pour chaque capteur inférieures à $4 \%$ montrent le haut niveau de performance et la bonne reproductibilité du nez électronique. Conclusion. Le nez électronique est sensible aux émissions volatiles de dattes. Toutes les variétés de datte étudiées ont été bien séparées. Cette technique rapide de criblage, qui crée une empreinte olfactive spécifique comme véritable carte d'identité, pourrait être utilisée pour suivre des changements de maturité, vérifier l'identité d'un bon nombre de dattes et détecter des adultérations.

Maroc / Pboenix dactylifera / fruits / variété / composé volatil / olfaction / instrument de mesure 


\section{Introduction}

Controlling fruit quality is a major challenge for agricultural development, where it is vital to differentiate products for both local and international markets. In addition, customer behavior cannot be ignored, with customers becoming more and more demanding. Controlling quality is a way of increasing the economic value of a crop, especially one such as dates, where it is also a means to protect and further develop the cultural and agricultural patrimony of a region. Indeed, increasing the value and thus economic returns due to dates would help to regenerate oases through the planting of date trees and thus help to stabilize emigration from southern Morocco [1].

Different techniques are available for assessing fruit quality. Biochemical, physical and chemical analyses are usually used to characterize the technological suitability of samples for different processes, but they are generally destructive. Aromas occupy a privileged position among quality markers [2], because they directly target the human olfactory center, which is a fast and highly selective decision tool.

However, detecting or characterizing volatile compounds first involves an extraction step. Two main processes are available: solvent extraction and headspace generation.

Solvent extractions are either liquid-liquid, based on the preference of the compound for two different immiscible liquids, usually a mix of polar and apolar organic solvents, or Lickens-Nickerson types that provide a good recovery of middle- and high-boiling-point molecules, but with the inconvenience of generating pollution artefacts due to the equipment or solvents [3]. To avoid these artefacts, super-critical carbon dioxide can be used as a solvent that is then easily removed as a gas $[4,5]$. However, the cost is still considerable and implementation is not easy.

The headspace fraction in equilibrium over a confined solid or liquid matrix [6] can be either static or dynamic [7]. Whereas static headspace tends to reach equilibrium, dynamic headspace, in purging the matrix with an inert gas, concentrates volatiles on a specific trap. It is closer to nasal percep- tion, emphasizing the light fraction of fruit aromas. The interest in using this technique to analyze date aromas as quality markers is increasing. Jaddou et al. [8] identified 27 aroma compounds and Reynes et al. [9] 36, while Harrak et al. [10] identified 47 molecules, 33 of which had not been previously referenced. They all agreed that aroma compounds could be used as specific markers to differentiate date varieties. Nevertheless, the weak aroma of dates is difficult to analyze. This type of analysis needs complex instruments like the gas chromatograph (GC) that can be combined with mass spectrometry (GC-MS). They are accurate and objective techniques, but relative to specific parts of the aroma and not always targeted to the fraction considered as determinant for human senses. In addition, they are timeconsuming and need qualified people for data interpretation.

Thus, date aroma would appear to be an interesting way to appreciate quality and to characterize different varieties. The current tendency is for a fast answer to a growing demand for information. A possible solution is the use of electronic-nose (e-nose) technology [11], which overcomes the main drawbacks of GC. It is a decision tool that can be rapidly and routinely used to assess product quality by checking the acceptability of flavors and volatile compounds relative to a finished product or incoming material.

The characterization of date genetic biodiversity for valorization is of considerable scientific and commercial interest. A genetic approach for characterizing dates using molecular biology gives good results [12], as does GC-MS [9]. Both of them are high-tech tools that try to find specific markers that will differentiate two or more samples. The global approach of the e-nose, comparable to near-infrared spectroscopy (NIRS), with a minimum handling of the sample, is a fast and efficient alternative to these techniques. The wider notion of a global fingerprint is favored, even though we know that some sensors preferentially react with certain kinds of molecules.

This rather new tool, simulating the behavior of the human nose, thus aroused our interest for application to dates. The instrument is based on Metal Oxide Sensors 
(MOS) that selectively adsorb the volatile emission from a sample. Then an olfactory fingerprint is built from the collected signals, creating, as it were, an identity card. Whether applied either to tomato, with a low sugar content and a faint aroma [13-15], or to mango, moderately sweet with a strong turpentine aroma [16], this technique is able to highlight differences between varieties and maturity grades. Dates have a high sugar content with high binding power for aromatic compounds. Therefore, the objective of our work was to determine if this type of rapid analysis is reliable and if it can give qualitative and quantitative information about date varieties.

\section{Materials and methods}

The date varieties Ademou, Black Bousthammi, Boufeggous, Bouslikhène, Bouskri, Jihel, Oum N'hal and Sair-Layalate were harvested ripe in 2005 (Tamar stage) from adult palm trees at the INRA experimental station in Zagora, Morocco. Dates of the DegletNour variety were also harvested ripe in 2005 from the El Oued area of Algeria. All dates were frozen after harvest and sent by air to the analytical laboratory of CIRAD (Montpellier, France); all data were collected at the same time.

Five hundred $g$ of dates were taken at random, pitted and cut into small pieces. After homogenization, an aliquot of $3.0 \mathrm{~g}$ was put into a $10-\mathrm{mL}$ headspace flask and immediately sealed. Six replicates per sample were prepared for later electronic-nose analysis. An electronic nose (e-nose) from Alpha MOS, equipped with Metal Oxide Sensors (MOS), was used. Data were analyzed using Principal Component Analysis (PCA).

The Prometheus e-nose (Alpha MOS, Toulouse, France) was equipped with a HS100 automatic headspace sampler (Alpha MOS) and with 18 metallic oxide sensors [LY type based on $\mathrm{Cr}_{2} \mathrm{O}_{3}+\mathrm{Ti}$ and $(\mathrm{P}$ and $\mathrm{T}$ ) type based on $\mathrm{SnO}_{2}+\mathrm{Pt}+\mathrm{Pd}$, coated and uncoated]. Samples were allowed to equilibrate for $2 \mathrm{~h}$ at room temperature on the HS 100 headspace sampler. The samples were then heated to $60^{\circ} \mathrm{C}$ and shaken for 15 min just before headspace sampling.

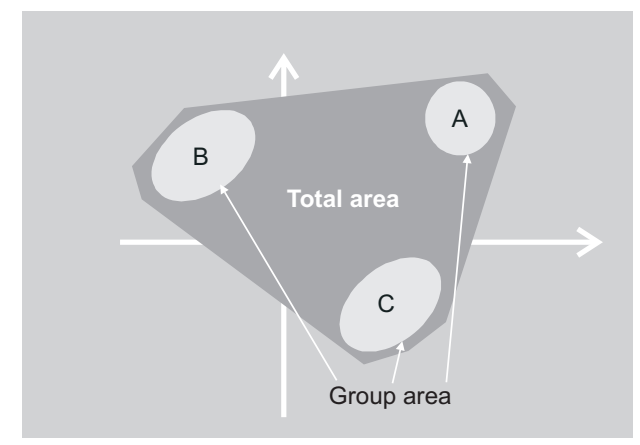

Figure 1.

Definition of the Discrimination Index (DI): $\mathrm{DI}=100 \times[1-$ (A area $+\mathrm{B}$ area $+\mathrm{C}$ area $) /$ (total area)]. A DI > 80\% indicates good discrimination and reliability.

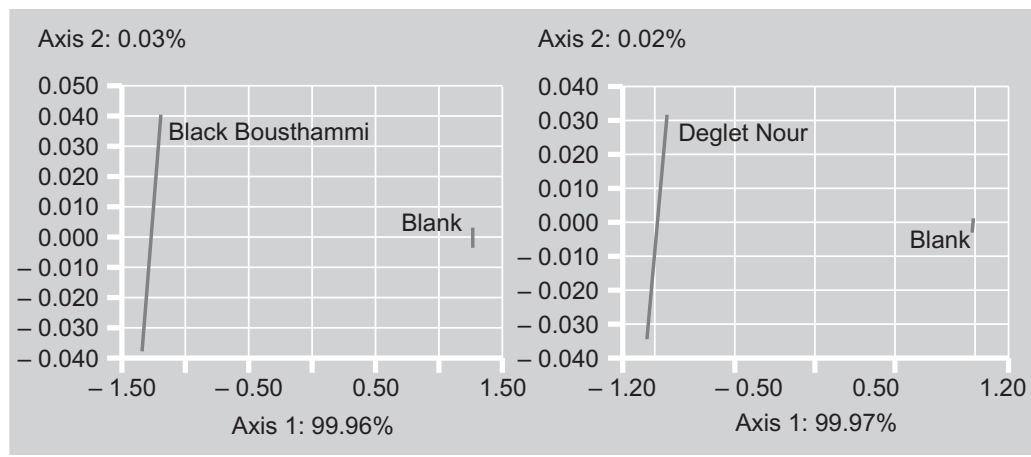

Headspace $(2000 \mu \mathrm{L})$, was injected at Figure 2.

$1500 \mu \mathrm{L} \cdot \mathrm{s}^{-1}$, into a $150 \mathrm{~mL} \cdot \mathrm{min}^{-1}$ flow of Principal component analysis pure air, generated by a N GC 3000 zero air of date volatiles characterized generator (Shmidlin-DBS, Switzerland). Sig- by e-nose showing that the two nal acquisition lasted $2 \mathrm{~min}$, followed by varieties Black Bousthammi $8 \mathrm{~min}$ for baseline recovery. The maximum and Deglet-Nour are clearly values on the adsorption/desorption curve different from their respective of each sensor (generally reached after $15 \mathrm{~s}$ ) were collected to build the olfactory fingerprint. Data were analyzed using Principal Component Analysis (PCA) performed on the Prometheus software Alpha soft V7 (Alpha MOS). The Discrimination Index (DI), created by Alpha MOS, was used to describe the discriminatory power of the groups' separation. Alpha MOS considers that good discrimination and reliability are achieved for DI over 80\% (figure 1).

\section{Results and discussion}

\subsection{Threshold of detection}

In order to demonstrate that dates produce a detectable olfactory fingerprint, we analyzed by e-nose the headspaces generated by two types of dates, Black Bousthammi lank samples (discrimination index = 99\%). 
Figure 3.

Principal component analysis of date volatiles characterized by e-nose: separation of nine date varieties on the first two principal components. Nine distinct groups corresponding to the nine varieties are clearly evident, with a discrimination index of $88 \%$ indicating good discrimination.

\section{Figure 4.}

Principal component analysis of date volatiles characterized by e-nose from pure samples of Black Bousthammi and Deglet-Nour dates and a 50\% mix of both varieties (discrimination index $=84 \%$ ).
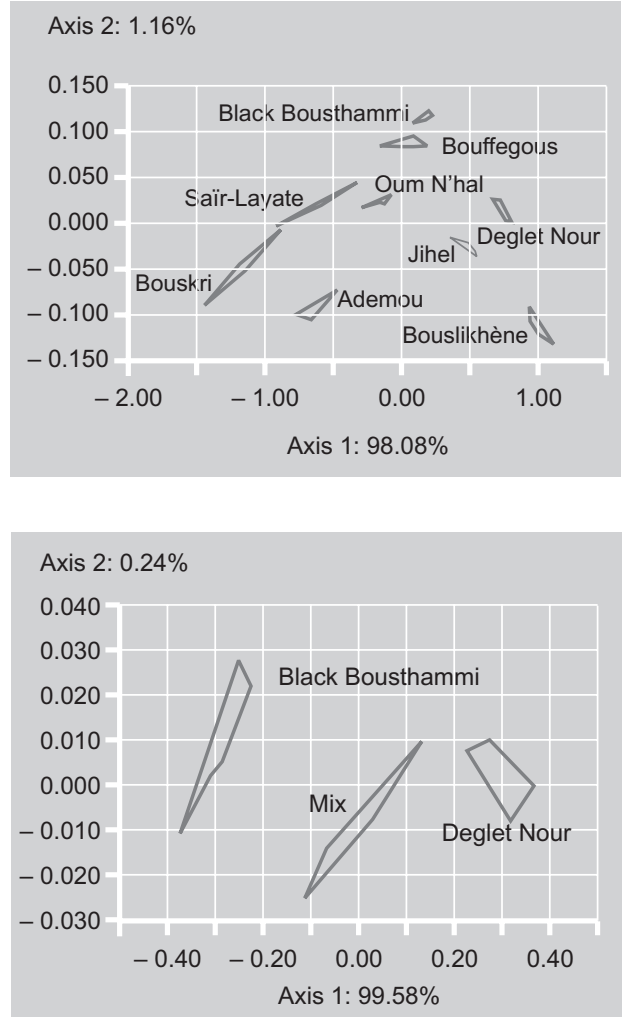

and Deglet-Nour. Both of them were compared with blanks (empty flask) (figure 2). Both graphs show distinct groups with DI $=99 \%$. The variation accounted for by the two principle axes was more than $99.9 \%$ for component 1 and less than $0.03 \%$ for component 2 . This indicates a good threshold of detection with respect to date aromas, which are generated in high quantity and detected by the e-nose. It also shows low sample population variability.

\subsection{Resolution}

The headspaces of nine different date varieties (Ademou, Black Bousthammi, Boufeggous, Bouskri, Bouslikhène, DegletNour, Jihel, Oum-N'hal and Sair-Layate) were analyzed to test the accuracy of e-nose resolution (figure 3). Nine distinct groups appeared on the subsequent PCA with $\mathrm{DI}=88 \%$. Most of the information is explained by the first two principle components (axis1: 98.08\%, axis2: 1.16\%). This demonstrates the excellent resolution of the e-nose and its power of segregation with respect to the dates' subtle aromas.

The separation of the date varieties on the second principal component appears to correlate with their firmness [17]. Black Bousthammi and Boufeggous are the softest varieties, followed by Deglet-Nour, Sair-Layalate and Oum-N'hal, which all have positive scores on axis2. The firmer varieties, due either to genotype or their rapid postharvest drying, all have negative scores on axis2. They are Bouskri and Jihel, followed by the firmest varieties Ademou and Bouslikhène. This raises the possibility that there are distinct volatile components that are consistently related to the texture of date fruits.

\subsection{Reproducibility}

In general, for the different groups identified by the e-nose, the average of the coefficients of variation of the responses of the different sensors is low and below 3.91\% (table I). This indicates good homogeneity between samples and good reproducibility of the sensors for volatile emissions from dates.

\subsection{Linearity}

Based on the good results achieved with the e-nose as a characterization tool, we projected a mixed sample of Black Bousthammi

\section{Table I.}

Average coefficients of variation of 18 e-nose sensors for nine varieties of dates.

\begin{tabular}{lc} 
Variety & $\begin{array}{c}\text { Coefficient of variation } \\
(\%)\end{array}$ \\
\hline Ademou & 1.98 \\
Black Bousthammi & 1.57 \\
Bouffegous & 3.52 \\
Bouskri & 3.03 \\
Bouslikhène & 2.99 \\
Deglet-Nour & 1.86 \\
Jihel & 2.51 \\
Oum-N'hal & 1.76 \\
Saïr-Layalate & 3.91
\end{tabular}


and Deglet-Nour (50\% each) on the PCA produced from the two pure varieties. The three sample types were clearly identified with a DI of $84 \%$ (figure 4). Euclidian distance between the groups of pure DegletNour and Black Bousthammi dates was 0.607 and the [50:50] mixed sample (mix $50 \%)$ in the plane of the first two principal components of the PCA was located halfway between the pure variety samples: 0.302 and 0.306 for the distance between mix 50\% and Black Bousthammi, and mix 50\% and Deglet-Nour, respectively. As previously described [18], the e-nose has a linear response and, even though few points are involved in the calculation, it is for this substrate a good indication of linearity. Using more robust models, such as Partial Least Squares regression (PLS) or Soft Independent Modeling Class Analogy (SIMCA), variety ratios in unknown samples could be determined, and from a qualitative point of view, the identity and purity of date lots certified.

\subsection{High through-put}

The drawback associated with the time needed for headspace generation is minimized, because for each sample it mainly occurs during the analysis and baseline stabilization of the previous sample. Thus data can be collected every $15 \mathrm{~min}$ and the e-nose can be considered as a fast screening technique.

\section{Conclusion}

Our study clearly shows the usefulness of the e-nose for assessing date varieties. Its performance concerning dates' volatile emissions, which are known to be weak, shows very good sensitivity and reproducibility (average of the coefficients of variation of the different sensors below 4\%). Most of the discrimination indices obtained were about 98\% (at least $>88 \%$ for the analysis of the nine varieties studied) and show the ability of the e-nose to distinguish easily varieties and mixes of varieties of dates sampled at the same level of ripeness. This fast screening technique, creating a specific olfactory fingerprint as a genuine identity card, could be used to follow changes in maturity, assure the identity of lots of dates and detect adulteration. Miniaturized devices, with date-specific sensors, would immediately have on-site application in the validation of date lots.

\section{References}

[1] Zirari A., Harrak H., Chetto A., Alaoui Rachidi M., Outlioua K., Réhabilitation de la diversité génétique du palmier dattier dans la palmeraie de Fezouata, Atelier du diagnostic participatif, Proj. RAB98G31 PNUD/FEM/IPGRI/ INRA, Gestion participative des ressources génétiques du palmier dattier dans les oasis du Maghreb, 2003, Zagora, Maroc, 96 p.

[2] Ackerman L.G.J., Torline P.A., Volatile components in the headspace of eight mango cultivars, Lebensm.-Wiss. Technol. 17 (1984) 339-341.

[3] Adda J., Richard H., Analyse des arômes : préparation des extraits en vue de l'analyse dans les arômes alimentaires, Richard H., Multon J.L. (Eds.), Tec \& DocLavoisier, Paris, France, 1992, pp. 258-273.

[4] Zadow J.G., Supercritical fluid extraction new technology for the food industry, CSIRO Food Res. Q. 48 (1988) 25-31.

[5] Gelu R., Les techniques d'extractions par fluides supercritiques appliquées à l'industrie aromatique, Ind. Agro-aliment. 106 (9) (1989) 765-769.

[6] Bicchi C., Joulain D., Headspace gas chromatography analysis of medicinal and aromatic plants and flowers, Flavour Fragr. J. 5 (1990) 131-145.

[7] Canela A.M., Muehleisen H., Application of headspace gas chromatography to the measurement of organic emissions, J. Chromatogr. 456 (1988) 241-249.

[8] Jaddou H., Mhaisen M.T., Al-Hakim M., Flavour volatile analysis of Zahdi dates by gas liquid chromatography, Date Palm J. 3 (2) (1984) 367-379.

[9] Reynes M., Lebrun M., Shaw P.E., Identification of volatile date components and use of multivariate analysis to distinguish date varieties, J. Food Qual. 19 (1996) 505-514.

[10] Harrak H., Reynes M., Lebrun M., Hamouda A., Brat P., Identification et comparaison des 
composés volatils des fruits de huit variétés de dattes marocaines, Fruits 60 (2005) 267278.

[11] Bartlett P.N., Blair N., Gardner J.W., Electronic noses. Principles, applications and outlook, Asic 12 (1993) 616-625.

[12] Al-Khalifah N.S., Askari E., Molecular phylogeny of date palm (Phoenix dactylifera L.) cultivars from Saudi Arabia by DNA fingerprinting, Theor. Appl. Genet. 107 (7) (2003) 1266-1270.

[13] Maul F., Sargent S., Balaban M. , Baldwin E.A., Huberd J., Luzuriaga D.A., Non destructive quality screening of tomato fruit using electronic nose technology, Proc. Fla. State Hortic. Soc. 110 (1997) 188-194.

[14] Maul F., Sargent S., Balaban M., Baldwin E.A., Huber D.J., Sims C.A., Aroma volatile profiles from ripe tomatoes are influenced by physiological maturity at harvest: an application for electronic nose technology, J. Am. Soc. Hortic. 123 (1998) 1094-1101.
[15] Maul F., Sargent S., Sims C.A., Balaban M., Baldwin E.A., Huber D.J., Tomato flavour and aroma quality as affected by storage temperature, J. Food Sci. 65 (7) (2000) 1228-1237.

[16] Lebrun M., Ducamp M.N., Plotto A., Goodner K., Baldwin E., Development of electronic nose measurements for mango (Mangifera indica) homogenate and whole fruit, Proc. Fla. State Hortic. Soc. 117 (2004) 421-425.

[17] Harrak H., Hamouda A., Boujnah M., Gaboune F., Teneurs en sucres et qualités technologiques et nutritionnelles des principales variétés de dattes marocaines, in: Boulanouar B., Kradi C. (Éds.), Symp. Int. Développement agricole durable des systèmes oasiens, INRA, Rabat, Maroc, 2005, pp. 108-115.

[18] Zhu L., Seburg R., Tsai E., Puech S., Mifsud J.C., Flavor analysis in a pharmaceutical oral solution formulation using an electronicnose, J. Pharm. Biomed. Anal. 34 (2004) 453-461.

\section{La nariz electrónica: un instrumento rápido y eficaz para la caracterización de los dátiles.}

Resumen - Introducción. Los aromas se emplean a menudo como marcador de la calidad del fruto. Para la caracterización de los dátiles (Phoenix dactylifera), varios investigadores emplearon el análisis de los compuestos volátiles. No obstante, es difícil de analizar este aroma contenido, a pesar de las numerosas técnicas disponibles, tales como las extracciones líquidolíquido y el análisis de espacio de cabeza. El uso de la nariz electrónica, que necesita una manipulación mínima de la muestra, es otra técnica; es rápida y eficaz. Este instrumento relativamente nuevo, que imita el comportamiento de la nariz humana, ha suscitado nuestro interés para una aplicación sobre los dátiles. Material y métodos. Se cosecharon los dátiles de nueve variedades de palmeras de dátiles, en 2005, en la fase Tamar, en Zagora, Marruecos. Tras la cosecha fueron congelados y enviados por avión al laboratorio del CIRAD (Montpellier, Francia). Se compilaron todos los datos al mismo tiempo. Se tomaron quinientos g de dátiles al azar mediante cosecha. Éstos se deshuesaron y se cortaron en trocitos. Tras homogeneización, se introdujo en un frasco con un espacio frontal de $10 \mathrm{~mL}$ una parte alícuota de $3.0 \mathrm{~g}$ y se selló inmediatamente después. Se prepararon seis repeticiones por muestra para los análisis posteriores mediante nariz electrónica. Se empleó una nariz electrónica (Alpha MOS) equipada de captadores a base de óxidos metálicos. Se trataron los datos mediante un análisis de componentes principales (ACP). El índice de discriminación (DI), creado por Alpha MOS, se empleó para describir el poder discriminatorio de la separación de grupos. Alpha MOS considera que se obtienen tanto una discriminación como una fiabilidad buenas para DI superiores al $80 \%$. Resultados. Los índices de discriminación superiores al 88 \% y las medias de los coeficientes de variación obtenidos para cada captador inferiores al $4 \%$ muestran el alto nivel de rendimiento y la buena reproductibilidad de la nariz electrónica. Conclusión. La nariz electrónica es sensible a las emisiones volátiles de los dátiles. Se separaron bien todas las variedades de dátiles estudiadas. Se podría emplear esta rápida técnica de reconocimiento, la cual crea una señal olfativa específica como verdadera tarjeta de identidad, con el fin de seguir los cambios de madurez, de verificar la identidad de un gran número de dátiles y de detectar las adulteraciones.

Marruecos / Phoenix dactylifera / frutas / variedades / compuesto volátil / olfacción / instrumentos de medición 